\title{
India-Pakistan Relations: International Implications
}

\author{
Alka Jauhari ${ }^{1}$ \\ ${ }^{1}$ Department of Government and Politics, Sacred Heart University, Fairfield, USA \\ Correspondence: Alka Jauhari, Department of Government and Politics, Sacred Heart University, Fairfield, CT, \\ USA. Tel: 1-203-365-4754. E-mail: jauharia@sacredheart.edu
}

\author{
Received: October 12, 2012 Accepted: October 31, 2012 Online Published: December 31, 2012 \\ doi:10.5539/ass.v9n1p42 URL: http://dx.doi.org/10.5539/ass.v9n1p42
}

\begin{abstract}
India's independence in 1947 from the British colonial rule and its subsequent division into two nations - India and Pakistan - has sowed the seeds of continuing conflict between the two countries since their independence. The partition of India was primarily based on the religious divide between the two communities - the Hindus and the Muslims. After India's partition, the major issue of conflict between the two countries has been the Muslim dominated northern state of Jammu and Kashmir, currently a part of India. This bilateral conflict has had international implications over the years. Decades of conflict, which includes three major wars, has contributed to a nuclear race between the two countries and growth of terrorism in the region. These two regional outcomes of the conflict have assumed global significance with the growing international threat of nuclear proliferation and terrorism.

The paper analyzes the bilateral conflict between India and Pakistan and the subsequent emergence of the global threats. The paper also emphasizes normalization of the bilateral relations as the key prerequisite to ensure peace and security for the region and also for relieving the global society from the perils of a growing nuclear threat and expanding forces of terrorism.
\end{abstract}

Keywords: conflict, nuclear, proliferation, terrorism, bilateral, international, peace, Kashmir, India and Pakistan

\section{Introduction}

India and Pakistan have had a history of conflict with each other ever since the independence of the Indian subcontinent, and its partition into India and Pakistan in 1947. The India-Pakistan conflict, which began as and is a bilateral conflict, got entangled with the international politics of the Cold War at the time of independence of the two countries. The Cold War, a post Second World War ideological conflict between the US and the Soviet Union, forced both the US and the Soviet Union to take opposing sides in the dispute between India and Pakistan. However, after the end of the Cold War, with the collapse of the former Soviet Union in 1991, the growth of terrorism and the proliferation of the nuclear weapons, the two key consequences of the conflict between the two countries, have given a new dimension to the bilateral conflict from an international perspective.

This paper will explore the international implications of the conflict between India and Pakistan.

Section I of the paper will analyze the origin and the growth of conflict between India and Pakistan in a historical context. Section II will highlight the underlying factors that have led to the proliferation of the nuclear weapons and terrorism in the region due to the growing conflict between the two nations. The regional and global implications of both nuclear proliferation and terrorism, as well as Pakistan's role in the war and the destabilization of Afghanistan will also be discussed in this section. Section III of the paper will analyze the policy alternatives for building peace between India and Pakistan, which are likely to enhance the prospects of maintaining peace and security at a broader international level. Section IV will conclude the paper, re-emphasizing the internationalization of the India-Pakistan conflict in terms of having unpleasant global consequences.

\section{The India-Pakistan Conflict}

India and Pakistan have shared a feeling of "mutual distrust" (Hewitt, 1997) ever since the partition of India and the eventual creation of Pakistan as an independent state. This distrust was an outcome of the colonial legacy of "divide and rule." The colonial policy of divide and rule pitted the Muslims against the Hindus. The policy gave rise, amongst the Muslim, to a sentiment of "Islam being in danger" (Hewitt, 1997) in the Hindu dominated 
Indian society. The growth of Islamic nationalism and hence the demand for a separate Muslim state was an outcome of this paranoia. On the other side, the belief within the Hindu dominated nationalist party of India was "secular Indian nationalism" (Ganguly, 1994). According to this belief, the Muslims could coexist with the Hindus under the Indian secular umbrella and, therefore, there was no necessity of a separate state.

Despite all efforts by the Indian nationalists to stall the partition at the time of independence, India was divided into two states, the Hindu-dominated India and the Muslim-dominated Pakistan. The British hurried into the partition because they did not want to get embroiled into what they thought to be the irreconcilable differences between the Hindus and the Muslims. Also, having suffered huge losses during World War II, the British lost the will to support their extended empires to resolve their internal conflicts. Thus, the Radcliffe Line (Note 1) was drawn on $17^{\text {th }}$ August, 1947, which officially demarcated the borders of the two countries.

The feeling of mutual distrust between the two countries, which got seeded during the British rule, continued even after independence. The mainstay of the distrust and, therefore, the conflict between India and Pakistan has been Jammu and Kashmir (Kashmir), a northern state in India. The "ideological orientations" of the Hindus and the Muslims, "Secular Indian Nationalism" and "Islam in Danger," became the basis for the Kashmir conflict between the two countries because the majority of the population in Kashmir is Muslim. The issue became more complicated because the ruler of Kashmir (Maharaja) was a Hindu and the population of Kashmir was predominantly Muslim. At the time of partition, the Maharaja signed the "instrument of accession," (Note 2) expressing his will to be a part of India. India, therefore, claims Kashmir to be a part of its territory by virtue of the signed accession. Pakistan, however, denies this claim. Pakistan's assertion is that the will of the people was not taken into consideration before signing of the accession agreement. This resulted in the first war between India and Pakistan in 1947. The Indian government supported the Maharaja of Kashmir and sent its armies to repel the attack on the western borders of Kashmir. Pakistan's army also got full fledgedly involved in the war. The war lasted for almost a year till the ceasefire agreement was signed, in January of 1949, as a result of the UN diplomatic effort. The ceasefire agreement, sponsored by the UN, required a withdrawal of the forces on both the sides and demarcated a new ceasefire line. The UN agreement also stipulated that a plebiscite should be held in Kashmir to take into account the will of the people. The government of India, however, failed to implement the last recommendation of the UN which became a sore point between India and Pakistan. The two countries have denied each other's claims on Kashmir resulting in a conflict which has gone on for more than six decades with no plausible solution in sight. India and Pakistan have fought two full-fledged wars on the issue of Kashmir and they have had a number of border skirmishes during the period.

\section{Internationalization of the India-Pakistan Conflict}

What was essentially a bilateral issue and a regional conflict has assumed international significance in the past couple of decades. Therefore, the conflict between India and Pakistan needs to be revisited in light of the developing international situation and its international implications. The internationalization of the conflict should be approached from two perspectives. In the past years, both India and Pakistan became involved in a race to acquire more and more nuclear weapons to strengthen their front against the other. This has aided and abetted the international nuclear arms race. In addition, acts of terrorism have been used as a potent tool to gain a winning edge in the bilateral conflict. Subsequently, international terrorism has grown manifold ever since the India-Pakistan conflict became marked by heinous acts of terror. The following sub-sections will explore the growth and internationalization of the issues of nuclear proliferation and terrorism in the context of the India-Pakistan conflict.

\subsection{Nuclear Proliferation}

India's nuclear journey began as early as in the 1950s. In 1952, the then Prime Minister Nehru unveiled a four year plan to begin developing India's nuclear infrastructure. In the initial years, India's nuclear program was designed towards using nuclear energy for civilian and peaceful purposes only. The direction of the program changed after India lost its territory to China in the Indo-China war of 1962. In 1964, China tested a nuclear weapon and in the same year India commissioned a reprocessing facility in Trombay. With the growing nuclear threat from China, India refused to sign the Nuclear Non-Proliferation Treaty (1968) and continued with its nuclear ambition to strengthen its defense, especially against China. Subsequently, India conducted its first peaceful nuclear explosion in Pokharan (Gujrat) in 1974.

Pakistan's call for expanding its nuclear program came in the 1960s and 1970s after its defeat in three full-fledged wars with India in 1947, 1965 and 1971. Pakistan desired to strengthen its defense against India. This resolve became even more pronounced after the Pokharan nuclear explosion by India. After the explosion, the then Prime Minister of Pakistan, Z.A. Bhutto, said "if India makes the bomb, we will eat grass or leaves, 
even go hungry, but we will get one of our own" (Sublette, 2002). In addition, Pakistan had relied heavily, during the Cold War years, on the US as a security guarantee against India. But the US failed Pakistan's expectations during the 1971 Indo-Pak war. The US naval ship USS Enterprise was deployed in the Indian Ocean during the war, but it did not take any action and very soon moved away from the region. The inaction was due to the fear of a regional war escalating into a war between the Cold War rivals with the possibility of the Soviet Union getting involved from India's side. The US attitude upset Pakistan and provided Pakistan with another rationale for strengthening its defense, especially against India, through acquisition of nuclear weapons.

The deteriorating relations between India and Pakistan after the 1971 war and the growing threat posed by a nuclear Pakistan, renewed India's resolve to continue its nuclear program designed to make nuclear weapons. This time the "nuclear protection" was rendered necessary for India not only to safeguard its northern borders (from China) but also to protect its western borders (from Pakistan).

Thus, throughout the 1980s and the1990s both India and Pakistan continued with their nuclear program for non peaceful purposes. India conducted a series of nuclear explosions in 1998 under "Operation Shakti." Pakistan conducted its own nuclear tests in the same year in response to India's nuclear ventures. Both faced international condemnation and periodic cuts of economic as well as military aid for their pursuit of nuclear weapons.

This bilateral race, to gain nuclear superiority, has had international implications in terms of fuelling the international arms race for nuclear weapons.

\subsubsection{International Implications}

The nuclear arms race between India and Pakistan and the subsequent nuclear threat has not remained confined to the region. The involvement of countries like Libya, Iran and North Korea in the nuclear proliferation ring has broadened the scope of the nuclear threat beyond the precincts of India and Pakistan.

1) Involvement of the outside powers in Pakistan's nuclear program

Pakistan is believed to have been clandestinely involved in developing nuclear relations with Iran and Libya ever since it began its nuclear endeavor in the 1970s. A. Q. Khan, the founder of Pakistan's nuclear program and also known as the father of the Pakistani bomb, has been the mastermind behind these relations. Khan's nuclear journey in Pakistan began with an effort to counter the nuclear power of Pakistan's enemy, India. After he returned to Pakistan from Switzerland in the mid 1970s, he gave to Pakistan the much sought after technology to make the nuclear bomb and thus assisted his country in neutralizing India's regional nuclear pre-eminence. However, with time, his nuclear network extended much beyond India. The underlying motivation for his call for proliferation was "pan-Islamism and hostility to western controls on nuclear technology" (Albright and Hinderstein, 2005). Thus, Khan befriended countries like Iran, Libya and North Korea through nuclear collaboration.

Khan's efforts to create a pan-Islamic nuclear proliferation ring resulted in collaborative ventures by Pakistan, like, "nuclear cooperation in exchange for oil program" with Iran and "missile for nuclear technology" barter arrangement with North Korea. The dangers of the expansion of the proliferation ring became clear when Iran designed its Shahab missile closely in the image of Pakistan's nuclear capable Ghauri missile. The design of Pakistan's Ghauri missile itself was based on North Korea's Nodong missile which corroborates the existence of a nuclear nexus between Pakistan, Iran and North Korea. The latest version of Iran's Shahab missile, Shahab 3, has a range of almost 800 miles which has put Iran's neighbors as well as Israel within the close range of the missile thereby threatening regional stability.

Khan also got involved in developing nuclear relations with Libya. The nuclear exchange between the two countries heightened the nuclear global threat especially in the background of the fact that Libya pursued an anti-US and anti-west policy during the 1980s and the 1990s under Gaddafi's regime. Empowered with a nuclear defense, Libya, under Gaddafi, successfully challenged the authority of other international players, especially the US, in the Mediterranean and the Middle Eastern region. Gaddafi's support to the anti-west revolutionary organizations, his outward criticism of the Camp David Accord (1978) (Note 3) and the Gulf of Sidra incident (1981) (Note 4) are all pointers to the growing haughtiness of Libya during this period. George W. Bush, the former President of the US, in his State of the Union address (2002) called Libya a part of "the axis of evil," with the potential to threaten international peace and security (Bush's "axis of evil" included Iran and Iraq along with Libya).

Pakistan's nuclear collaboration with other countries under the guidance of Mr. Khan has extended the nuclear threat from the bilateral to the global level. Despite clear indications and self-admittance by Khan of running a proliferation ring, he was pardoned by the then President of Pakistan, General Pervez Musharraf, and was put 
under house arrest. In 2008 Khan implicated General Musharraf of being aware of all the nuclear deals undertaken by him. Khan's assertion vilified General Musharraf's involvement in Khan's nuclear game plan - a clear corroboration of the fact that Pakistan's leadership has not only been involved in the development of the nuclear program but also in the proliferation of the nuclear threat.

2) The Indo-US Nuclear partnership has spurred the nuclear race

Another factor that has given a dangerous dimension to the nuclear race between India and Pakistan is the tacit acceptance by the United States of India's nuclear status in the past few years. The eagerness of the United States to balance Beijing's power in South Asia and also its perception of India being a "responsible nuclear power" has determined US's policy framework in the region. In addition, recognition of Pakistan's growing links with terrorism and also its clandestine nuclear program has led the US to circumvent Pakistan's nuclear ambitions. The veritable outcome of US's new overture was the signing of the nuclear deal between US and India in 2006. Although the deal is for using nuclear technology for peaceful purposes, India has still welcomed US's support. India has an underlying desire to gain nuclear superiority to maintain its regional pre-eminence and US has vouchsafed India's desire through the nuclear deal. The deal between India and the United States was concluded despite the fact that India has decided not to open most of its nuclear facilities for international inspection. The US has happily acceded to India's position. Also, the deal went through irrespective of India's non-commitment to the Nuclear Non Proliferation Treaty and India's decision to conduct a series of non-peaceful nuclear tests in the 1990s. No such deal was offered by the US to Pakistan. The Indo-US nuclear partnership has increased Pakistan's paranoia and has pushed it into the arms of other estranged powers. In order to enhance its nuclear capability and be at par with India, Pakistan is now courting with China. Although China had provided nuclear assistance to Pakistan in the past in developing the technology to build gas centrifuges, the Indo-US nuclear partnership has given a new impetus to Pakistan-China nuclear relations. Subsequent to the signing of the nuclear deal between India and the US, the visit of the then President of Pakistan, Pervez Musharraf, to China, was an affirmation to revive nuclear cooperation between the two countries. China also did not welcome the US-India nuclear deal with much enthusiasm because the deal undermined China's own political ambitions in the region. Thus, China eagerly agreed to pacify Pakistan's fear about the changing regional nuclear balance. China's state-run China National Nuclear Corp (CNNC) got involved in building nuclear reactors for Pakistan. In February, 2011, the CNNC signed a deal to build two nuclear reactors with a capacity 300 megawatt. The CNNC has recently proposed to build a one gigawatt nuclear plant in Pakistan which will be much more powerful than the other four.

The nuclear arms race between India and Pakistan, so supported by the US and the Chinese, has also had a spillover effect on the deterioration of relations between the United States and China. It has fueled the Cold War between the US and China. China has been competing against the United States to surpass US's geo-political influence and the US has subsequently been making attempts to crush China's ambitions. China's nuclear involvement with Pakistan is seen by the US as a challenge to US's dominance and its supremacy in nuclear matters in the region. Therefore, the US has been eager to have a nuclear partnership with India. China's and the US overtures have actually diminished the possibility of any cooling down of the conflict situation between India and Pakistan. It has, in fact, become a vicious cycle. India's nuclear collaboration with the US has resulted in Pakistan re-discovering its nuclear ties with China. This has in turn led to the US and China getting more and more embroiled in the India-Pakistan conflict. In order to establish their sway in the region, both, the US and China have been assisting their respective nuclear partners and in the process they have further deepened the conflict between India and Pakistan. Deepening conflict has once again necessitated more support from the outside powers.

3) A failed Pakistani state can be a dangerous omen

After independence, Pakistan's political history has been inimical to a genuine democracy. A democratically elected government has never lasted its full term in Pakistan. The democratic political leadership changed three times in the 1990s before finally being thrown over by a military coup in 1999. Ever since, Pakistan has became a breeding ground for the extremist groups who often seek refuge in unstable societies. These groups found greater succor in Pakistan in the 1990s and early 2000s. The stability of the current democratic government has also been put at stake by these extremist elements. There is a growing fear among the political analysts that if the current government fails, Pakistan may degenerate into being a failed state.

A failed Pakistani state can be a dangerous omen for the international society considering the fact that control over nuclear weapons could easily pass into the hands of the fundamentalists. The release of Mr. Khan from 
house arrest, in 2009, has increased this fear considering that Khan is suspected to have passed on nuclear secrets to Al Qaeda during the Taliban regime in Afghanistan.

After Khan was released from house arrest, the state department in the US expressed concerns in the background of the belief that Al-Qaeda has approached Khan to obtain nuclear weapons material. The government of Pakistan assured the United States government that Khan will be kept under tight scrutiny. However, the request by the western countries for an investigation into his proliferation activities has been repeatedly denied by the Pakistani government. Although there is a ban on his foreign travel but he is allowed to move around freely within the country. This has been rendered dangerous by the western countries considering the strong presence of the extremist elements in Pakistan.

\subsection{Terrorism}

The conflict between India and Pakistan for control over Kashmir has had a direct bearing on the issue of terrorism, both regionally and internationally. The conflict, which resulted in three full-fledged wars between the two countries in 1947, $1965 \& 1971$, has had a dangerous outcome in the form of growth of terrorism in the region. After being humbled in the three wars with India, Pakistan realized the weaknesses of its military defense. The 1947 and the 1965 wars were fought by the two nations to directly assert their respective control over Kashmir. The 1971 war, which was fought in the eastern sector, was about the secession of the eastern wing of Pakistan (which became the independent nation of Bangladesh in1971) from the western mainland. The war, however, considerably undermined Pakistan's claim on Kashmir which was based on religion. East Pakistan, like Kashmir, had a predominantly Muslim population. It became evident that Pakistan had to "find new allies to fight the asymmetric warfare against India" (Reidel, 2008). Subsequently, in the 1990s, a new trend of external insurgency began in the Kashmir, apparently with the tacit support of the Pakistani Intelligence Agency (ISI), after the end of the Cold War (Note 5). The insurgent groups like, Harakat-ul-Mujahideen (HUM), Jaish-e-Mohammed (JEM) and Lakshar-e-Taiba (LET), which were earlier members of the Afghan Mujahideen group - Muslims involved in Jihad (Holy War) - assumed distinct group identities and became active in fighting for the freedom of Kashmir. During the Cold War, the Mujahideen fought against the 1979 Soviet invasion of Afghanistan. Once the Cold War ended, the Mujahideen redirected their attention to Kashmir with their growing empathy for the Pakistani claims on the region. In the 1990s there were a series of terrorist attacks in India which began in Kashmir and then gradually spread to other regions by the year 2000 - the Delhi parliamentary attack in 2001, Bangalore bombings in 2006 and more recently the Mumbai attacks in 2008.

In addition, a new international development during this period gave the Mujahideen a new rationale and a new focus for Jihad, along with the war in Kashmir. Iraq's invasion of Kuwait in 1990 and the subsequent role played by the US and the rest of the western world (Note 6) in the 1991 Gulf War (Note 7) resulted in an anti-west rhetoric in the Mujahideen circles. The west was implicated of trying to take control of the Gulf region and was also criticized for violating the Muslim faith by stationing soldiers from the west in the Muslim holy land. As a result, a Mujahideen group, Al-Qaeda, orchestrated and undertook a series of attacks against the west on the western territories and also on western locations world-wide, to express their resentment. The 1993 bombing of the World Trade Center, bombing of the US embassies in Kenya and Tanzania, USS Cole in 2000, 9-11 in 2001, 2004 Madrid train bombings and 2005 London underground train attacks, were all an outcome of the same rhetoric.

At the core of these attacks has been the role played by the Mujahideen groups. Although these groups operate under different names, they all have often worked in collusion with each other. The operations of these groups and the terrorist acts undertaken by them have had unpleasant regional and global consequences.

\subsubsection{International Implications}

As in the case of the nuclear arms race, the terrorist threat has also broadened in scope beyond the territorial boundaries of India and Pakistan.

1) Pakistan has become the epicenter of the terror matrix.

The terrorist groups responsible for the terrorist attacks in India and those involved in the attacks on the western territories have worked collaboratively and Pakistan has become the headquarters of their activity. HUM, JEM and LET have been operating from Pakistan ever since their creation. After 9-11, when Al-Qaeda and Taliban (Note 8) were routed from Afghanistan by the US and NATO (Note 9) troops, they also sought refuge in the neighboring Pakistan.

The Pakistani authorities were believed to have been fully cognizant of the operations of these groups. The ISI not only supported the Jihadi groups in Afghanistan, including Al-Qaeda and Taliban, it also promoted 
insurgency and radicalism in Kashmir through LET, HUM and JEM. Pakistan has become the hub and the common operational ground of the terrorist groups which has facilitated the nexus between these groups.

The Mujahideen faction, HUM, the orchestrator of terrorist attacks in Kashmir and the mastermind of the Indian Airlines jet hijacking in 1999, is also known to have been providing assistance to individuals planning "jihadi" attacks on the western targets. HUM participated in Osama Bin-Laden's "fatwa" (declaration of war) against the US, Israel and the rest of the west. "Fatwa" (adopted in 1996) highlighted the "sufferings of the people of Islam and the injustices imposed on them by the Zionists and the Crusaders" and therefore, the necessity to establish an "Islamic World Front for struggle against the Jews and the Crusaders" ("fatwa" text PBS News Hour). The confluence of the two groups and their declaration of war against the western world have led to the establishment and operation of training camps by them around the world to undertake terror attacks on the foreign territories.

Another group, LET, which moved its operations from Afghanistan to Kashmir after the end of the Cold War, has also been implicated of orchestrating terrorist attacks beyond the Indo-Pak borders. LET was involved in a terror plot against the Danish newspaper which published the cartoons of Prophet Mohammed. The governments of US, UK and Australia have declared LET as a terrorist organization. Britain's Terrorism Act of 2000 has proscribed LET activities for its clear links with the UK born "jihadists" (Horne and Douse; 2012). In addition, LET, which has openly proclaimed Hindus and Jews as enemies of Islam and has regarded India and Israel as enemies of Pakistan, has also been supporting and fighting alongside Al-Qaeda and Taliban against the NATO alliance in Afghanistan. The group has been charged of training, funding and sheltering of the terrorists involved in the World Trade Center attack in the US in 1993 and also those involved in the terror attacks in Philippines and Chechnya.

Similarly, JEM, which started its operations primarily with the purpose of integrating Kashmir into Pakistan, has also declared a war against the US. JEM has obvious links with Al-Qaeda and Taliban. The group is known to have been involved in the kidnapping and murder of the American journalist Daniel Pearl. Furthermore, JEM has declared a domestic war within Pakistan against the home government's ties with the US. JEM was responsible for the 2001 attack on the Indian Parliament and was also responsible for the assaults on the Christian sites in Pakistan in 2002.

The nexus of terror, as described above, has posed and continues to pose a threat to the region as well as to the world beyond the borders of India and Pakistan.

\section{2) Pakistan shifting away from the war in Afghanistan}

Another international implication of the bilateral conflict between India and Pakistan and the resulting terrorism has been the US fear of losing Pakistan as an ally in US's war in Afghanistan. After every terrorist attack on India, Pakistan's focus shifts to its eastern sector, with India alerting its armies on its borders with Pakistan. Therefore, the western allies, especially the US, have been insisting on the two countries to resolve their bilateral issues peacefully so that Pakistan can redirect its war efforts on the western borders.

In the aftermath of the 2001 terrorist attack on the parliament of India, the then President of Pakistan, Pervez Musharraf, moved his troops from the western borders to the eastern borders and thereby jeopardized the US's operations in Afghanistan. Collin Powell, President Bush's secretary of state, was rushed to the region to diffuse tensions between the two countries. After the Mumbai attacks in November, 2008, Condoleezza Rice, the secretary of state during former President Bush's second term, employed diplomacy to end the escalating tensions on both the sides. During her visit to the region after the attacks, Rice claimed that there was no military stand-off between the two countries and that the two governments are working in cooperation to apprehend the perpetrators of the act.

The US has to play a very calculated and effective diplomacy in the region to protect its interests in Afghanistan. US did not pay much attention to the external insurgency in Kashmir after the end of the Cold War. But the recent spate of terrorist attacks in India, outside of Kashmir, cannot be ignored by the US, especially, after having experienced itself the brunt of these attacks on September 11, 2001. At the same time, however, the US also has to recognize the necessity to hold on to Pakistan as an ally in US's war in Afghanistan and in its war against global terrorism. Underscoring the importance of the issue, the Obama administration, within one month into office, appointed Richard Holbrooke as the special envoy to Afghanistan and Pakistan. A major effort of the special envoy was directed to facilitate a dialogue with Pakistan to help US's cause in Afghanistan. The primary focus of both the Bush administration and the Obama administration has been the resolution of conflict between India and Pakistan so that Pakistan remains an effective military partner of the US in Afghanistan, without being distracted by the skirmishes on its borders with India. 


\section{3) The potential threat of destabilization of Afghanistan}

The Indo-Pak conflict and the resulting growth of terrorism have also threatened the stability of Afghanistan. As a result, the conflict has had implications for the international forces fighting in Afghanistan. Afghanistan has been that wild card which Pakistan has always needed to tilt the regional balance in its favor. Ever since independence, Pakistan's Afghan policy has been focused towards “forming an alliance with Afghanistan and undermine any potential partnership between India and Afghanistan, to prevent Pakistan's encirclement by India" (Pande 2011). The strategic partnership between Pakistan and Afghanistan reached its pinnacle during the Taliban rule in Afghanistan (1996-2001). Afghanistan, under Taliban, joined hands with Pakistan in the latter's fight against India over Kashmir. This was the time when the Mujahideen groups from Afghanistan redirected their efforts towards Kashmir in India. Thus, the 1990s saw a surge in the terrorist activity in Kashmir and also in the rest of India. After Taliban was routed from Afghanistan and was replaced by the Northern Alliance of Ahmed Karzai, the partnership between Pakistan and Afghanistan also broke down. The new Afghanistan looked towards India for partnership and assistance. India on its part welcomed Afghanistan's offer because India's national interest lay in a friendly Afghanistan which would put pressure on Pakistan from the western sector while India took charge of the eastern sector. Pakistan has been naturally apprehensive of this new alliance between India and Afghanistan. A neighbor, also a former ally, forging a partnership with India is not in the national interest of Pakistan which was evidenced in the bombing of the Indian embassy in Kabul in which senior ISI members were known to have been involved. Pakistan's fear of "pincer squeeze" (Pande 2011) between its eastern and the western sectors has resulted in its tacit support of the Taliban, which has been waging a war against the foreign forces to regain its control in Afghanistan. Such an attitude has had broader negative implications on the endeavors of the NATO and the US forces to establish stability and security in Afghanistan.

\section{Conflict Resolution}

Since the bilateral conflict between India and Pakistan has become intertwined with broader security concerns internationally, resolution of the conflict has assumed greater importance in the current times. Such a resolution is not only integral to the establishment of peace and security between India and Pakistan but it is also imperative for the maintenance of international peace and security.

As mentioned in the narrative above, the feelings of mutual distrust have vitiated the environment between the two countries ever since the time of their independence in 1947. Therefore, the first step towards managing the conflict should be to break the tide of mistrust and adopt the approach of "Confidence Building" (Subramanyam 1993). Building trust and confidence will require an open dialogue between the two countries. As a next step, collaborative efforts to strengthen the security of the region will go a long way to initiate peace in the region. The two together, "Building Confidence and Security Building Measures" (CSBMs) (Subramanyam 1993) could become the key underlying force towards conflict resolution between India and Pakistan, both, on the nuclear issue as well as on the issue of terrorism.

\subsection{The Issue of Nuclear Proliferation}

Nuclear arms race has been a major deterrent to trust building between India and Pakistan. Therefore, it is pertinent that a nuclear dialogue should be started between the two countries as an initial gesture to secure peace. For the purpose,

"The two sides should set out their perceptions of each other's nuclear efforts and make explicit their concerns."(Subramanyam 1993)

In this context, an assurance for not using the nuclear weapons first would be a good start. Unfortunately, Pakistan has not committed itself to any such initiative despite the explicit statement by the former Prime Minister of India, Atal Bihari Bajpyee, that India will not preempt the use of nuclear weapons. On the contrary, the former military ruler of Pakistan, Pervez Musharraf, blatantly declared that Pakistan will not hesitate to use nuclear weapons if the Indian army crosses the ceasefire line. Pakistan currently is under democratic governance with civilian leaders in control of its politics. Here is an opportunity for Pakistan to make that commitment and help in the process of confidence building. During his first year as the Prime Minister of Pakistan, Yusaf Raza Gilani (2008-2009), had admitted that "the country was mindful of its responsibilities as a nuclear weapon state as well as its international obligations." But no practical measures were adopted by the former Prime Minister since then, which could be said to have been directed towards the enforcement of his candid assertion.

In addition, negotiations and dialogue between the two countries need to be stepped-up in order to resolve the nuclear issue. The nuclear talks in region should, in fact, be a "tripartite" endeavor including India, Pakistan and the US. The recent US - India nuclear partnership has raised apprehensions in the Pakistani circles pushing them 
into the arms of other nuclear powers like China and North Korea. A concerted effort should be made by India and the US to allay the fears of Pakistan by laying on the table a full account of the nuclear doctrine of both the states in the region.

Such confidence building measures will assist in bringing the two, India and Pakistan, to the table to discuss the deeper issue of Kashmir. Kashmir conflict was one of the motivating factors for Pakistan to enhance its nuclear program in order to gain an edge in its asymmetric wars with India. Confidence building on the nuclear issue can facilitate a dialogue between the conflicting states on the issue of Kashmir and any headway on the Kashmir front can reduce the necessity of amassing nuclear weapons.

\subsection{The Issue of Terrorism}

The issue of terrorism has also assumed greater significance in the past couple of decades in determining relations between India and Pakistan. Terrorist attacks on the Indian soil, supposedly sponsored by the Pakistani Jihadi groups, have heightened the feeling of mistrust between the two countries and have therefore undermined the possibility of conflict resolution, especially on the issue of Kashmir. In light of the growing acts of terrorism in India, the first initiative towards confidence building has to come from the Pakistani leadership. Unless Pakistan's government takes a proactive action against the perpetrators of terrorist attacks, any efforts towards a dialogue on Kashmir will remain unsuccessful. In the past, both India and Pakistan have attempted to address the Kashmir conflict through the initiation of dialogue. But these endeavors towards a constructive engagement have been undermined due to the environment of mistrust developed because of the periodic terrorist attacks. The meetings between India and Pakistan have largely ended up in finger pointing without any plausible solution to the fundamental issues. India's concern for cross border terrorism sanctioned by Pakistan and Pakistan's constant denial of the charge has marked usual the tenor of these meetings, which has jeopardized any efforts towards effective reconciliation.

Now that Pakistan itself has become a victim of the home grown terrorism in the past couple of years, it will be prudent for the Pakistani authorities to crack down on the terrorist groups which are known to have been operating from its own territory. The foremost confidence building measure in this situation would be to apprehend and try the perpetrators of the 2008 Mumbai attacks in India. In addition, Pakistan ought to make efforts to uproot the terrorist bases of groups like HUM, LET and JEM which have been evidentially held responsible for the terrorist attacks in India. In the absence of such endeavors, any attempt to a dialogue runs the risk of being lost in exchanges of mutual acrimony, as observed in the $25^{\text {th }}$ February, 2010 meeting between the two countries. Some progress however, has been reported in terms of thawing of relations between India and Pakistan in the past couple of years.

The "confidence building measures" actually demonstrated their merit in the talks held between the foreign ministers of India and Pakistan in July, 2011. "Both sides announced some concrete confidence building measures, including discussions on counter terrorism measures (especially progress in the Mumbai attacks trial in Pakistan), and promotion of interactions between the people of Indian-administered and Pakistani-administered Jammu and Kashmir" (Puri 2011). The meeting eventually translated into the signing of the "21 point joint statement" between the two countries. The joint statement highlights the importance of resolution of the outstanding issues of disputes between the two countries and the potential threat thereof, including the threat of terrorism and the nuclear arms race. As a follow up to this initiative, the most recent visit of India's External Affairs Minister, Mr. S.M. Krishna, in September 2012, further reaffirms the resolve of both the countries to establish peace by carrying forward the process of dialogue.

Despite these conciliatory gestures, it is still premature to celebrate peace and friendship between the two countries because "outside the mainstream political space, the forces bent upon acting as spoilers, still remain active" (Puri 2011). These actors could be the conservative elements on both sides of the fence. In India, these constitute the groups who are seeking revenge from Pakistan for their involvement in the terror attacks in India and on Pakistan's side it is the even tougher fundamentalist elements, the terrorist organizations. The latter have particularly been successful in jeopardizing efforts towards reconciliation between India and Pakistan by orchestrating timely acts of terror. These acts have time and again derailed all peace efforts.

\section{Conclusion}

The India-Pakistan conflict, which began in 1947 after the independence and the subsequent creation of the two states, has assumed an international character in the past couple of decades. The two veritable outcomes of the conflict, nuclear proliferation and terrorism, have not only destabilized the region but have also posed a threat to international peace and security. What was originally a bilateral conflict, now, has unpleasant international implications. The conflict has involved many other countries with the growing nuclear cooperation of India and 
Pakistan with their respective nuclear partners. The nuclear threat has become all the more dangerous considering the political instability in Pakistan and the subsequent fear of the extremists getting their hands on the nuclear installations in Pakistan. The conflict between the two countries has also resulted in terrorism, especially the one practiced by the Jihadists, becoming a global threat with more and more acts of terror happening world-wide. Therefore, it is pertinent to address the bilateral conflict with positive initiatives from both the sides, India and Pakistan, to ensure stability not only for the region but also for the international society at large.

\section{References}

Albright, D., \& Hinderstein, C. (2005). Unraveling the A. Q. Khan and Future Proliferation Networks. Retrieved 2011, July 11, from: http://www.twq.com/05spring/docs/05spring_albright.pdf

Ganguly, S. (1994). The Origins of War in South Asia (2nd ed.). Boulder; Westview Press, Inc.

Hewitt, V. (1997). The New International Politics of South Asia (1st ed.). New York; Manchester University Press.

Horne, A., \& Douse, D. (2012). The Terrorism Act 2000: Proscribe Organizations. Retrieved July 30, 2011, from: $\mathrm{http} / /$ www.google.com/url? sa $=\mathrm{t} \& \mathrm{rct}=\mathrm{j} \& \mathrm{q}=\& \mathrm{esrc}=\mathrm{s} \& \mathrm{frm}=1 \&$ source $=$ web\& $\mathrm{cd}=5 \& \mathrm{ved}=0 \mathrm{CEIQFjAE \& url}=\mathrm{h}$ ttp\%3A\%2F\%2Fwww.parliament.uk\%2Fbriefing-papers\%2FSN00815.pdf\&ei=Y6Q_UNzWAq6I6AHowo HICA\&usg=AFQjCNH78ATmEygiZ6Xrd4G34dj1dgvB3g\&sig2=cul4nMQI2FD0DfGBk6yc3A

Pande, A. (2011). Explaining Pakistan's Foreign Policy: Escaping India. Routledge, New York.

PBS News Hour. (1996). Bin Laden's Fatwa. Retrieved July 30, 2011, from http://www.pbs.org/newshour/terrorism/international/fatwa_1996.html

Puri, L. (2011). India and Pakistan's Surprisingly Successful Negotiations. Retrieved October 22, 2012, from http://afpak.foreignpolicy.com/posts/2011/07/28/india_and_pakistans_surprisingly_successful_negotiations

Reidel, B. (2008). Pakistan: The Critical Battlefield. Current History, 107(712).

Sublette, C. (2002). Pakistan's Nuclear Weapons Program: The Beginning. Retrieved July 25, 2011, from http://www.nuclearweaponarchive.org/Pakistan/PakOrigin.html

Subrahmanyam, K. (1993). Capping, Managing or Eliminating Nuclear Weapons? In Kanti P. Bajpai, \& Stphen P. Cohen (Eds.), South Asia after the Cold War. Boulder Westview Press, Inc.

\section{Notes}

Note 1. India and Pakistan (West and East) were divided at the time of partition on the basis of the border commission report. The commission was headed by Sir Cyrill Radcliffe. The Radcliffe Line defined the international borders between India and Pakistan.

Note 2. The Indian Independence Act of 1947 included the document of the "instrument of accession," whereby the princely states were given an option to accede to the dominion of India. The Maharaja of Kashmir signed the document and thus, Kashmir acceded to India.

Note 3. An agreement signed between Egypt and Israel, which led o the first peace treaty between Israel and an Arab country. The agreement was facilitated through the good offices of US president, Jimmy Carter.

Note 4. A naval and air combat between the US and Libya, in response to Libya's assertion of its control over the region.

Note 5. Cold War was an ideological war between the United States of America (sponsoring capitalism and free market enterprise) and the former Soviet Union (adhering communism). Both the powers desired to spread their respective ideologies and establish their supremacy in the world politics. The cold war began in 1947, after the Second World War, and ended in 1991 with the collapse of the Soviet Union and its communist ideology.

Note 6. Primarily the countries from Western Europe and also countries from other lands, especially from the Americas, who have adopted the western European culture.

Note 7. War between the UN sanctioned coalition force, led by the US, and Iraq, for Iraq's illegal invasion of the neighboring Kuwait. (accessed July 25, 2011).

Note 8. Islamic militant group which ruled Afghanistan from 1196-2001. Taliban practiced the conservative Islamic policies and is also known to have provided shelter to the Mujahideen group Al-Queda. 
Note 9. North Atlantic Treaty Organization (NATO), is a collective defense system between the countries in the north Atlantic region, which was set up after the Second World War to deter any external attack on the member states. 